\title{
Reaction-to-fire performance of fire-retardant treated wooden facades in Japan with respect to accelerated weathering
} \author{
Hayakawa $^{7}$ \\ ${ }^{1}$ Tokyo University of Science (TUS), Japan \\ ${ }^{2}$ National Institute for Land and Infrastructure Management (NILIM), Japan \\ ${ }^{3}$ The University of Tokyo, Japan \\ ${ }^{4}$ Japan Testing Center for Construction Materials (JTCCM), Japan \\ ${ }^{5}$ Koshii \& Co, Ltd, Japan \\ ${ }^{6}$ Misawa Homes Co., Ltd., Japan \\ ${ }^{7}$ Tokyo System Vac. (TSV), Inc., Japan
}

Miki Nakamura $^{1}$, Hideki Yoshioka ${ }^{2, a}$, Manabu Kanematsu $^{1}$, Takafumi Noguchi ${ }^{3}$, Shinji Hagihara ${ }^{4}$, Akio Yamaguchi ${ }^{5}$, Ken Shimizu ${ }^{5}$, Toshiyuki Sugita ${ }^{6}$, Yumi Matsumoto ${ }^{3}$, Yuhei Nishio ${ }^{3}$ and Tetsuya

\section{INTRODUCTION}

Wood has been used for building facades to enhance the aesthetic design of buildings since the revision to the evaluation method associated with the amendment of the Building Standard Law of Japan in 2000. In response, wood that has been pressure-impregnated with fire retardants (fire-retardant treated wood) is often used to ensure it is safe in the event of a fire. Currently, when fire-retardant-treated wood is tested for certification of reaction to fire performance, a cone calorimeter test is conducted in Japan. This test applies radiant heat to the surface of a square specimen, $100 \mathrm{~mm}$ each side, immediately after it has undergone fire-retardant treatment. However, when applying fire-retardant treatment to wood, aqueous chemical injection is the standard procedure. When wood is actually used to construct a building, there is a concern about environmental forces such as wind and rain that could cause the wood to deteriorate, and concerns about performance degradation associated with aging. One of the past studies in Japan [1] conducted a cone calorimeter test after an outdoor exposure test and accelerated weathering test, compared the post-test performance with the initial performance and confirmed the amount of remaining fire retardant in the treated wood had been reduced. However, no comparison of the fireproof performance of fire-retardant wood in actual use in a building facade had been conducted in Japan. There have been already valuable researches [e.g. 2,3] on this issue internationally, but this paper is the first step in Japan and authors hope to focus on the wooden façade construction technique and the standard façade test in Japan.

\footnotetext{
ae-mail: yoshioka-h92te@nilim.go.jp
}

This is an Open Access article distributed under the terms of the Creative Commons Attribution License 2.0, which permits unrestricted use, distribution, and reproduction in any medium, provided the original work is properly cited. 
Table 1. Combination of accelerated-weathering and reaction-to-fire tests.

\begin{tabular}{|c|c|c|c|c|}
\hline \multirow{2}{*}{ Method } & \multicolumn{2}{|c|}{ Accelerated-weathering test } & \multicolumn{2}{c|}{ Reaction-to-fire test } \\
\cline { 2 - 3 } & Standard & Specimen size & Standard & Specimen size \\
\hline 1 & JSTM J 7001 & $1.980 \times 1.980 \mathrm{~mm}$ & $\begin{array}{l}\text { IIS A 1310 } \\
\text { Façade test }\end{array}$ & $\begin{array}{c}1.820 \mathrm{~mm} \text { (width) } \\
4.095 \mathrm{~mm} \text { (height) }\end{array}$ \\
& & & $\begin{array}{c}\text { ISO 5660-1 } \\
\text { Cone test }\end{array}$ & $100 \mathrm{~mm} \times 100 \mathrm{~mm}$ \\
\hline 3 & NT FIRE 053 & $130 \times 500 \mathrm{~mm}$ &
\end{tabular}

Table 2. Overview of specimens.

\begin{tabular}{|c|c|c|c|c|c|c|}
\hline \multicolumn{2}{|r|}{ Specimen } & \multirow[t]{2}{*}{ Wood } & \multirow[t]{2}{*}{ Thick } & \multicolumn{2}{|c|}{ Fire retardant } & \multirow[t]{2}{*}{ Coating } \\
\hline & & & & Type & Amount & \\
\hline $\mathrm{A}$ & Fire-retardant treated & \multirow{4}{*}{ cedar } & \multirow{4}{*}{$18 \mathrm{~mm}$} & \multirow{3}{*}{$\begin{array}{l}\text { Phosphoric } \\
\text { acid }\end{array}$} & $172 \mathrm{~kg} / \mathrm{m}^{3}$ & \multirow{3}{*}{ Paraffin } \\
\hline $\mathrm{B}$ & $\begin{array}{l}\text { Fire-retardant treated, and } \\
\text { JSTM J } 7001\end{array}$ & & & & $131 \mathrm{~kg} / \mathrm{m}^{3}$ & \\
\hline $\mathrm{C}$ & $\begin{array}{l}\text { Fire-retardant treated, and } \\
\text { NT FIRE } 053\end{array}$ & & & & $139 \mathrm{~kg} / \mathrm{m}^{3}$ & \\
\hline $\mathrm{D}$ & $\begin{array}{l}\text { No fire-retardant treated or } \\
\text { accelerated-weathering }\end{array}$ & & & - & - & \\
\hline
\end{tabular}

Under these circumstances, this study aims to discuss a method to evaluate the reaction-to-fire performance of fire-retardant-treated wood used as building facades with aging deterioration taken into consideration. To be specific, a building facade fire-spread test in Japan (JIS A 1310) [4, 5] and cone calorimeter test (ISO 5660-1) [6] were conducted on specimens that had undergone an accelerated weathering test so as to compare their performance and make fundamental reviews.

\section{OUTLINE OF THE EXPERIMENTS}

The combination of accelerated-weathering and reaction-to-fire tests in this study is shown in Table 1. Two kinds of accelerated-weathering test were conducted - NT FIRE 053 [7], one of the generally accepted standard tests especially in North Europe, and the Japanese standard test method (JSTM J 7001) [8]. Two kinds of reaction-to-fire test were conducted - a facade test that assumes an actual fire (JIS A 1310) and a small-scale test (cone calorimeter test, ISO 5660-1). Assuming aging deterioration of fire-retardant-treated wood, an accelerated weathering test was conducted, which was then followed by a reaction-to-fire test. The fire properties were compared among the two tests, and the burning condition of the fire-retardant wood after the accelerated weathering test was compared with that of non-treated wood.

\subsection{Outline of specimens}

The specimens were as described as in Table 2. The wood used was 18 -mm-thick cedar lumber pressureimpregnated with a fire retardant. Phosphoric acid was used as a fire retardant to increase its fire retardant performance with the thermal insulation effect in the solid phase. Paraffin was used as the coating and it is insoluble in water. The concentration of the fire retardant impregnated in specimens (A) was $22.9 \%$. Specimens (A) were only treated with a fire retardant and not subject to an accelerated weathering test. The fire retardant agent with a concentration of $23.5 \%$ was impregnated in JSTM J7001 specimens (B) and NT FIRE 053 specimens (C). The weight of the specimens was measured after impregnation of the chemical to calculate the amount of the impregnated chemical agent. The average amount of the agent was $172 \mathrm{~kg} / \mathrm{m}^{3}$ for $\mathrm{A}, 131 \mathrm{~kg} / \mathrm{m}^{3}$ for $\mathrm{B}$, and $139 \mathrm{~kg} / \mathrm{m}^{3}$ for $\mathrm{C}$. The impregnated amount of $\mathrm{A}$ was the greatest among them. 
$2^{\text {nd }}$ International Seminar for Fire Safety of Facades, Lund (Sweden), 2016

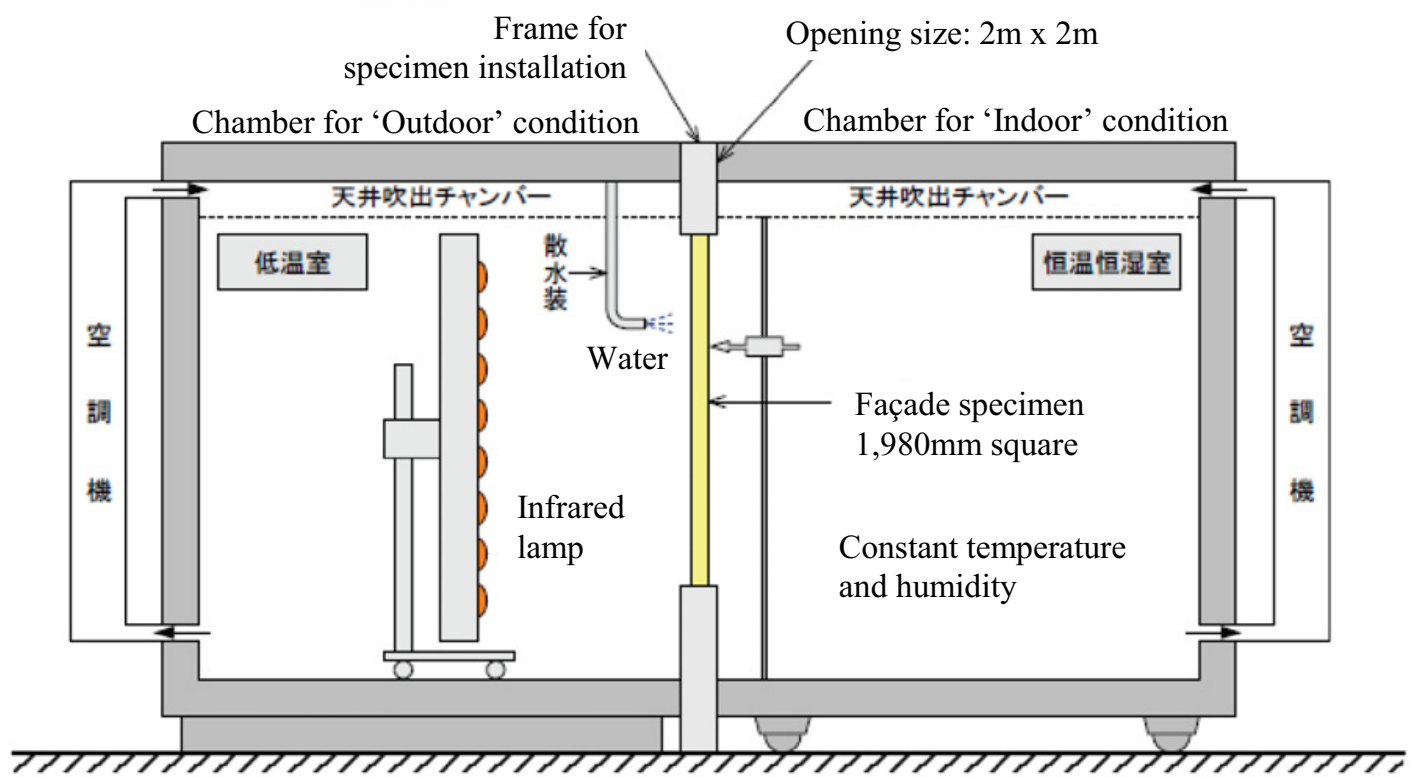

Figure 1. JSTM J 7001 test apparatus.

\subsection{Accelerated weathering test - 1 (JSTM J 7001)}

An accelerated weathering test was conducted on two specimens, each with surface dimensions of $1980 \times 1980 \mathrm{~mm}$, according to the Japan Testing Center for Construction Materials standard (JSTM J 7001) durability test method. It is usually used as durability test for exterior facades in general, but in this research it is applied to be used as accelerated-weathering for fire-retardant treated wooden facades. An outline of the test equipment is shown in Fig. 1. Specimens were installed on a specimen installation frame set up between the two chambers, one for outdoor condition and another for indoor condition, according to the actual installation procedure. Specimens were heated for 4 hours and then cooled for 4 hours. This eight-hour process was set as one cycle. A total of 90 cycles were conducted for the specimens. For heating, an insolation device with an infrared lamp was used to irradiate the surface of a specimen until the surface temperature rose to $80^{\circ} \mathrm{C}$. For cooling, water was sprinkled at a rate of 1 litter $/\left(\mathrm{m}^{2} \cdot \mathrm{min}\right)$ at the beginning, and the temperature was lowered to $-20^{\circ} \mathrm{C}$.

\subsection{Accelerated weathering test - 2 (NT FIRE 053)}

An accelerated weathering test was conducted according to Northern European standard NT FIRE 053 Method A. To be specific, four specimens, each measuring $130 \times 500 \mathrm{~mm}$, were placed with the longer side slanted to $18^{\circ}$. Water was sprinkled for 96 hours and the specimens were dried for 72 hours as one cycle. Four cycles were conducted in the test. The temperature of the water sprinkled ranged from $2{ }^{\circ} \mathrm{C}$ to $16^{\circ} \mathrm{C}$. Water was sprinkled over the surface through a spray nozzle from above the specimen. To make conditions more equal in the water sprinkling for all specimens, the layout of each specimen was changed every cycle so that the average sprinkling volume on the specimen's surface remained at $0.32 \mathrm{~L} /\left(\mathrm{m}^{2} \cdot \mathrm{min}\right)$. To prevent water from being sprinkled on the specimen edges and the fire retardant from leaching from the edges, the specimen surfaces were coated with sealant. The inside of the test equipment was kept between $57^{\circ} \mathrm{C}$ and $60^{\circ} \mathrm{C}$ during drying, and wind with an average velocity of $19.3 \mathrm{~m} / \mathrm{min}$ was blown over the specimen surfaces. 
Table 3. Details of accelerated-weathering tests.

\begin{tabular}{|l|l|c|c|}
\hline \multicolumn{2}{|l|}{} & JSTM J 7001 & NT FIRE 053 \\
\hline Time for one cycle & $8 \mathrm{~h}$ & $168 \mathrm{~h}$ \\
\hline Number of cycle for conducting & 90 cycles & 4 cycles \\
\hline \multirow{3}{*}{ Heating } & Total time & $360 \mathrm{~h}$ & $288 \mathrm{~h}$ \\
\cline { 2 - 4 } & Temperature & $80^{\circ} \mathrm{C}$ & $60^{\circ} \mathrm{C}$ \\
\hline \multirow{3}{*}{ Cooling } & Total time & $360 \mathrm{~h}$ & $384 \mathrm{~h}$ \\
\cline { 2 - 4 } & Temperature & $-20^{\circ} \mathrm{C}$ & $2 \sim 16^{\circ} \mathrm{C}$ \\
\hline \multirow{3}{*}{ Watering } & Total time & $15 \mathrm{~h}$ & $384 \mathrm{~h}$ \\
\cline { 2 - 4 } & Amount of water per minute & $1 \mathrm{LTR} /\left(\mathrm{m}^{2} \cdot \mathrm{min}\right)$ & $0.3 \mathrm{LTR} /\left(\mathrm{m}^{2} \cdot \mathrm{min}^{2}\right.$ \\
\cline { 2 - 4 } & Total amount of water & $900 \mathrm{LTR} / \mathrm{m}$ & $6912 \mathrm{LTR} / \mathrm{m}^{2}$ \\
\hline
\end{tabular}

The method of conducting the accelerated weathering test used is described in Table 3 . The temperature difference that occurred between heating and cooling was $100^{\circ} \mathrm{C}$ for JSTM J 7001 and $50{ }^{\circ} \mathrm{C}$ for NT FIRE 053. During the former method, the surface temperature dropped to below $0{ }^{\circ} \mathrm{C}$, and dew condensation eventually occurred. The amount of water sprinkled per minute was greater for JSTM $\mathrm{J}$ 7001, whilst the total amount of sprinkling water that the specimen surface received throughout the test was greater for NT FIRE 053.

\subsection{Reaction-to-fire test - 1 (cone calorimeter test)}

The cone calorimeter test was conducted according to ISO5660-1. The specimen surface was cut to a size of $100 \times 100 \mathrm{~mm}$ after the accelerated weathering test, and the specimens were kept intact and dried for about one week until the water content before the cone test reached about $10 \%$. A cone test was conducted by heating a specimen at a position $25 \mathrm{~mm}$ away from the electric heater at a heating intensity of $50 \mathrm{~kW} / \mathrm{m}^{2}$ for $20 \mathrm{~min}$. The mass of each specimen was measured during heating to calculate the mass reduction ratio. The oxygen concentration was also measured to calculate the heat release rate using the oxygen consumption method.

\subsection{Reaction-to-fire test - 2 (facade test)}

An outline of the equipment used for the facade test JIS A 1310 is shown in Fig. 2. After accelerated weathering test (JSTM J 7001), each specimen was modified to have surface dimensions of $1820 \times$ $4095 \mathrm{~mm}$ and opening dimensions of $910 \times 910 \mathrm{~mm}$. Facade specimens were set in place so that the burning chamber matched the opening of the specimen, and the burner in the chamber was ignited to let the flames gush out from the opening. The heating intensity in the chamber was set to $1200 \mathrm{~kW}$, the heating time was $20 \mathrm{~min}$, and thermocouples were installed in a total of 19 positions in the vent layer between the specimen and the substrate and a total of 5 positions on the specimen surface (Fig. 3). Heat flux meters were installed on the top surface of the specimen, the center of the opening on the surface facing the specimen $2000 \mathrm{~mm}$ away, and heights of 0, 500, 900, 1500, 2000, and $2500 \mathrm{~mm}$ from the top of the opening. The oxygen concentration in the exhaust duct during the experiment was measured, and the heat release rate was calculated using the oxygen consumption method.

\section{EXPERIMENT RESULTS AND DISCUSSION}

\subsection{Results of cone calorimeter tests (ISO5660-1)}

The damage condition of the burned surface before and after the cone calorimeter test is shown in Fig. 4. The results of JSTM J 7001 specimens B showed almost the same tendency between the two specimens. Thus, the result of B-1 is shown as a representative specimen. No major change occurred to the size of specimen A, which was only treated with a fire retardant, and B-1 from before and after the cone test. 
$2^{\text {nd }}$ International Seminar for Fire Safety of Facades, Lund (Sweden), 2016

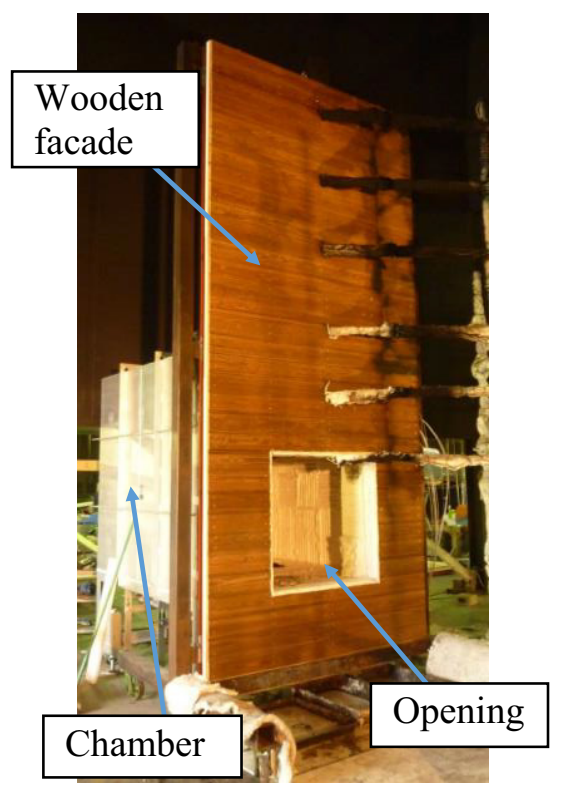

Figure 2. JIS A1310 facade test equipment.

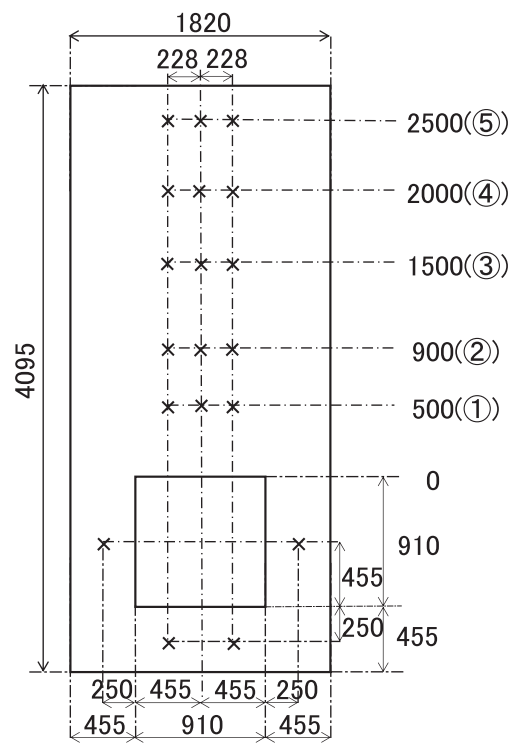

Figure 3. Layout of thermocouples (unit: $\mathrm{mm}$ ).

The NT FIRE 053 specimen C and non-treated specimen D became smaller than before the cone test, carbonized after the test, and showed gloss on their rear surface.

The measurement results and the results of heat release rate and total heat released are shown in Table 4, Fig. 5, and Fig. 6, respectively. Although no difference occurred between A and B in terms of heat release rate and total heat released, $\mathrm{C}$ ignited $9.7 \mathrm{~min}$ after the start of heating, and its heat release rate became a maximum $13.6 \mathrm{~min}$ after the start of heating. D ignited, its heat release rate peaked 


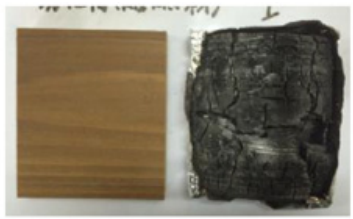

(a) Specimen A:

Fire-retardant treatment only

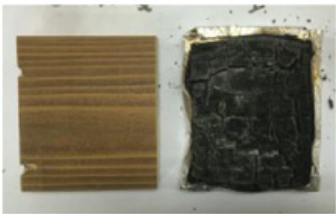

(b) Specimen B-1:

Fire-retardant treated and JSTM J 7001

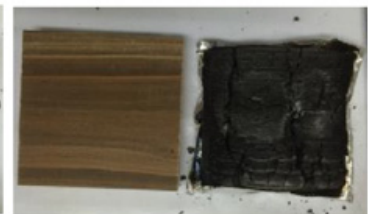

(c) Specimen C:

Fire-retardant treated and NT FIRE 053

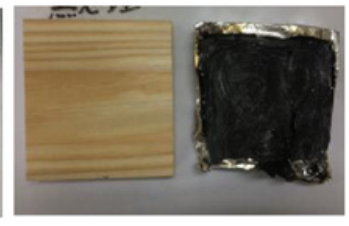

(d) Specimen D: No treatment

Figure 4. Damage on the burned surface before and after the cone calorimeter test. (left: before test, right: after test).

immediately after the start of heating, and the peak occurred again after $12 \mathrm{~min}$. B still maintained a sufficient amount of fire retardant to prevent ignition even after the accelerated weathering test. C had much of its fire retardant leached in the accelerated weathering test and ignited. It is speculated according to the condition of the rear of specimen $\mathrm{C}$ after the cone test that the specimen was burned to its rear in a burning process that reached the peak. For the burning condition of $\mathrm{D}$, it is speculated that specimen burning became moderate after the first peak because the carbonized layer that formed on the wood surface shut off the burning process, and then another peak occurred because the rear of the specimen began burning.

The resultant mass reduction rate and comparison of specimens $\mathrm{A}, \mathrm{B}$, and $\mathrm{C}$ that all contained fire retardants indicated that the larger the mass before the heating test, the larger the mass reduction rate would likely become. This is presumably because the more fire retardant remains in a specimen before the heating test, the more is leached during burning.

In order for a building material/product to be certified in Japan regarding reaction-to-fire performance, the total heat released must be $8 \mathrm{MJ} / \mathrm{m} 2$ or less, in 5 minutes for flame retardant material, $10 \mathrm{~min}$ for quasi-noncombustible material, and $20 \mathrm{~min}$ for noncombustible material. Specimens $\mathrm{A}, \mathrm{B}$, and $\mathrm{C}$ exceeded $8 \mathrm{MJ} / \mathrm{m} 2$ in $15 \mathrm{~min}, 13.4 \mathrm{~min}$ and $9.6 \mathrm{~min}$ after the start of heating, respectively. These results show $\mathrm{A}$ and $\mathrm{B}$ have the performance of quasi-noncombustible material and that $\mathrm{C}$ has the performance of flame-retardant material. As for the result of the accelerated weathering test, the condition of B showed just leaching of some fire retardant, while the condition of $\mathrm{C}$ showed much more leaching of fire retardant. These results confirmed the deteriorated performance of the specimens subjected to the accelerated-weathering test.

The dry densities of specimens before the cone test were $0.51 \mathrm{~g} / \mathrm{cm}^{3}$ for A, $0.43 \mathrm{~g} / \mathrm{cm}^{3}$ for B-1, $0.40 \mathrm{~g} / \mathrm{cm}^{3}$ for B-2, and $0.37 \mathrm{~g} / \mathrm{cm}^{3}$ for C. B and C had a smaller dry density than A, which suggests that the fire retardant of these two specimens was leached as a result of the accelerated-weathering tests. Comparing B and C, C had a smaller dry density than B. This is presumably because $\mathrm{C}$ had a lot of its fire retardant leached as a result of a large amount of water being sprinkled and a long duration of water sprinkling during the accelerated-weathering test and its dry density before the cone test eventually was reduced.

\subsection{Results of facade tests (JIS A 1310)}

The damage condition and burned area of each specimen after completion of the facade fire test are shown in Fig. 7. A $100 \times 100 \mathrm{~mm}$ lattice metal net was put over each specimen after completion of the test, and the burned condition such as burn-through or carbonization was checked for each space. The burn-through height was $1,500 \mathrm{~mm}$ for $\mathrm{A}, 2,000 \mathrm{~mm}$ for B, and 2,700 $\mathrm{mm}$ for $\mathrm{C}$, while the burn-through area was $0.84 \mathrm{~m}^{2}$ for $\mathrm{A}, 1.35 \mathrm{~m}^{2}$ for $\mathrm{B}$ and $4.23 \mathrm{~m}^{2}$ for $\mathrm{C}$ (see Table 5). Comparing the specimens after burning, specimen D suffered a wider area of burning than A or B. A comparison between A and B 
$2^{\text {nd }}$ International Seminar for Fire Safety of Facades, Lund (Sweden), 2016

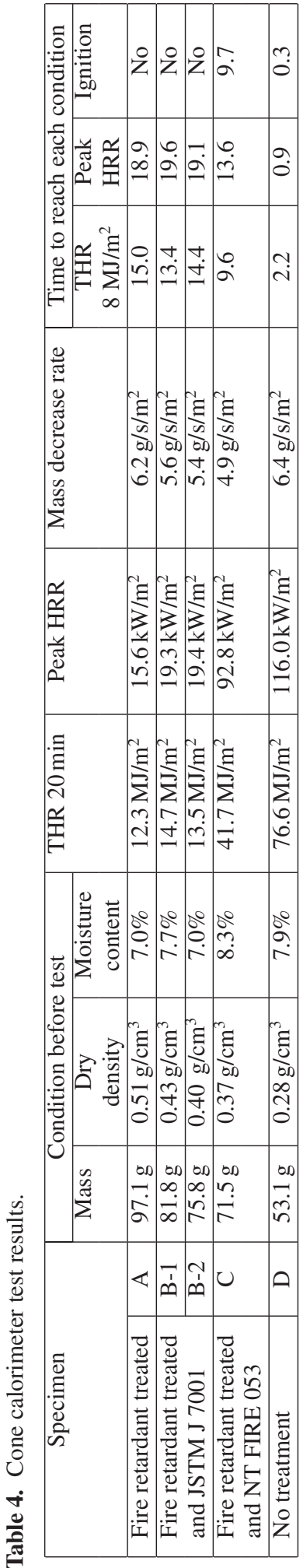




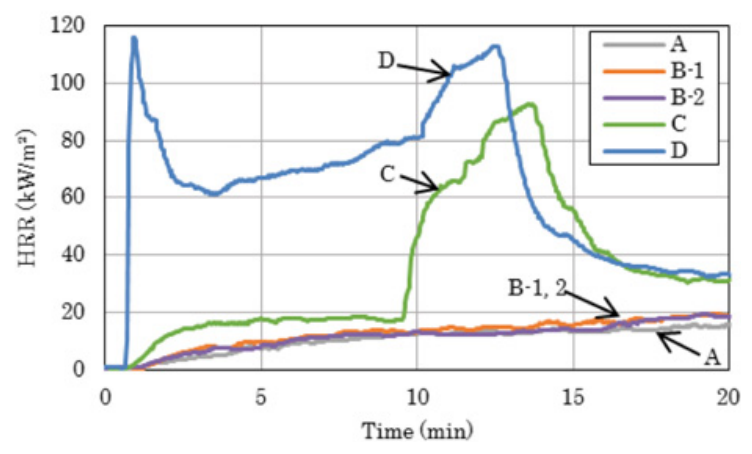

Figure 5. Cone calorimeter test: heat release rate.

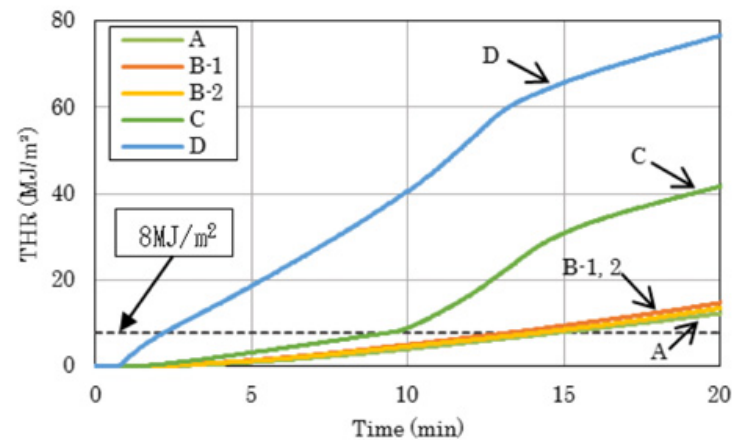

Figure 6. Cone calorimeter test: total heat released.

indicated the burning had spread slightly more for B than A. The fire retardant contained in A and B was leached on the surface and ran down after the facade test, and it was seen even from the lower part of the opening that was not exposed to the flame during the test. It is shown that the temperature rise causes leaching of the fire retardant. In addition, part of the surface at the upper part of specimen A fell off after the test, just as if it was shaved off. This is a sign that the amount of the leached fire retardant was greater for A than B and that the area beside the opening was more intensely carbonized for A than B (see Fig. 8). Specimens A and B share a similar burning tendency. Immediately after the start of the test, they both gave off a burning sound, the surface wood sprang up, and the fire was automatically extinguished after completion of heating. On the other hand, specimen D had all its surface burned immediately after the start of test, the burning sound started in 3 minutes, ash started to fly off from the surface thereafter, and self-burning continued even after the end of the test (end of heating from chamber).

Temperature changes on the specimen surface and at the vent layer (right-side from centreline) are shown in Fig. 9. Temperature changes at the vent layer located right side from centreline are shown here, because the thermocouples situated at the centreline of the vent layer, which was installed down the vertical furring strip, did not show any major temperature change during the façade test. The trend of temperature rise on the surface is almost the same for A and B. The temperature rose soon after the start of heating at $500 \mathrm{~mm}$ and $900 \mathrm{~mm}$ above the opening, while the temperature softy rose at $1,500 \mathrm{~mm}, 2,000 \mathrm{~mm}$ and 2,500 $\mathrm{mm}$ above the opening. On the other hand, all the surface temperatures started to rise for D immediately after the start of heating, and only the temperature rise at $500 \mathrm{~mm}$ shows almost the same trend for D, as A and B. Regarding temperature changes at the right-side 

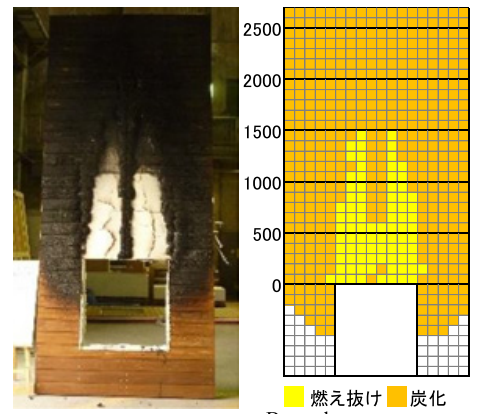

Burned Carbonize

(a) Façade specimen A:

Fire-retardant treatment only.
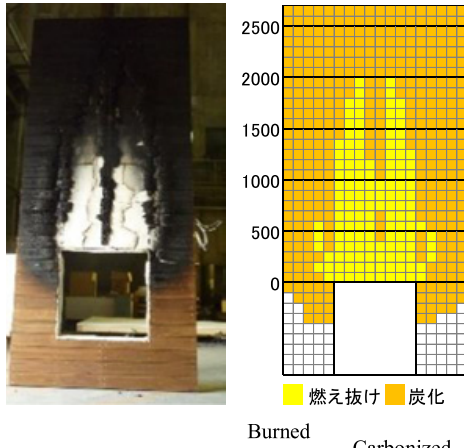

through

Carbonized

(b) Façade specimen B:

Firstly, fire-retardant treated, and then, JSTM J 7001 conducted.
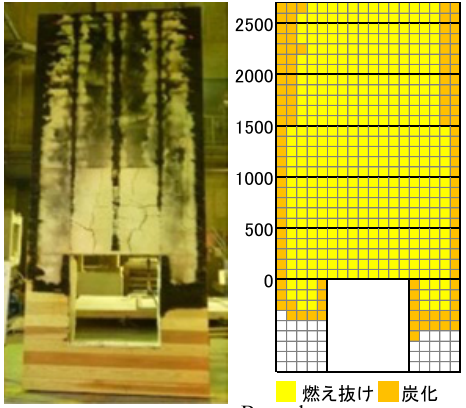

燃え抜け炭化

through Carbonized

(c) Façade specimen D: No treatment at all (cedar).

Figure 7. Damage condition and the burned area after the facade test.

Table 5. Overview of JIS A 1310 façade test results.

\begin{tabular}{|c|c|c|c|c|c|c|c|c|c|c|c|}
\hline \multirow{2}{*}{\multicolumn{2}{|c|}{ Specimen }} & \multicolumn{2}{|c|}{$\begin{array}{l}\text { Portion of burned- } \\
\text { through area at } \\
\text { façade after the test }\end{array}$} & \multicolumn{5}{|c|}{$\begin{array}{c}\text { Time when the } \\
\text { façade specimen was burned } \\
\text { through from surface to substrate }\end{array}$} & \multirow[t]{2}{*}{$\begin{array}{l}\text { Peak Heat } \\
\text { Flux at top } \\
\text { of facade }\end{array}$} & \multirow[t]{2}{*}{$\begin{array}{l}\text { Peak } \\
\text { HRR* }\end{array}$} & \multirow[t]{2}{*}{$\begin{array}{l}\text { THR* } \\
20 \mathrm{~min}\end{array}$} \\
\hline & & Height & Area & $\begin{array}{l}500 \\
\mathrm{~mm}\end{array}$ & $\begin{array}{l}900 \\
\mathrm{~mm}\end{array}$ & $\begin{array}{c}1500 \\
\mathrm{~mm}\end{array}$ & \begin{tabular}{|c|}
2000 \\
$\mathrm{~mm}$
\end{tabular} & $\begin{array}{c}2500 \\
\mathrm{~mm}\end{array}$ & & & \\
\hline $\begin{array}{c}\text { Fire } \\
\text { retardant treated }\end{array}$ & A & $1.5 \mathrm{~m}$ & 0.84 & $\begin{array}{c}13 \\
\min \end{array}$ & $\begin{array}{l}15.5 \\
\min \end{array}$ & - & - & - & $11.7 \mathrm{~kJ}$ & $1,361 \mathrm{~kW}$ & $1,350 \mathrm{M}$. \\
\hline $\begin{array}{l}\text { Fire retardant } \\
\text { treated and } \\
\text { JSTM J } 7001\end{array}$ & B & $2.0 \mathrm{~m}$ & $1.35 \mathrm{~m}^{2}$ & $\begin{array}{c}10 \\
\min \end{array}$ & $\begin{array}{l}12.5 \\
\min \end{array}$ & $\begin{array}{l}14.5 \\
\mathrm{~min}\end{array}$ & $\begin{array}{l}19.5 \\
\min \end{array}$ & - & $11.0 \mathrm{~kW} / \mathrm{m}^{2}$ & $1,306 \mathrm{~kW}$ & 1,348 MJ \\
\hline $\begin{array}{c}\text { No } \\
\text { treatment }\end{array}$ & D & $2.7 \mathrm{~m}$ & 4.231 & $\begin{array}{c}8 \\
\min \end{array}$ & $\begin{array}{l}8.5 \\
\min \end{array}$ & $\begin{array}{l}10.5 \\
\text { min }\end{array}$ & $\begin{array}{l}11.5 \\
\min \end{array}$ & $\begin{array}{l}12.5 \\
\min \end{array}$ & $32.9 \mathrm{~kW} / \mathrm{m}^{2}$ & $1,796 \mathrm{~kW}$ & 1,788 \\
\hline
\end{tabular}

* Heat release values (peak and total) include the contribution of gas burner.

vent layer, the temperature rise time at each measurement point decreases in descending order from A to $\mathrm{B}$ to D. Assuming the time when the temperature at the right-side vent layer almost matches the surface temperature is equal to the time when a façade specimen surface is burned through, then the burn-through time at $500 \mathrm{~mm}$ is $13 \mathrm{~min}, 10 \mathrm{~min}$, and $8 \mathrm{~min}$ for $\mathrm{A}, \mathrm{B}$ and $\mathrm{D}$, respectively, while that at $900 \mathrm{~mm}$ is $15.5 \mathrm{~min}, 12 \mathrm{~min}$ and $8.5 \mathrm{~min}$ for A, B and D, respectively. Table 5 tabulates those differences among the specimens. Burn-through was visually confirmed up to $1,500 \mathrm{~mm}$ with specimen A, while the temperature at $1,500 \mathrm{~mm}$ at the right-side vent layer did not reach the surface temperature. B was burnt through up to $2,000 \mathrm{~mm}$, and $\mathrm{C}$ was burnt through up to $2,500 \mathrm{~mm}$. These results confirmed that fire-spread further expanded after the accelerated weathering test was conducted to the façade specimen, but it is still more moderate than the cedar specimen without fire-retardant treatment.

\subsection{Comparison of reaction-to-fire test results}

The cone calorimeter results were compared among the specimens A, B and D. While a difference was confirmed for D from the other two, no major difference was observed between A and B. And regarding the facade tests, their results are almost the same as those of the cone calorimeter test for A, B and D in terms of the visual records and surface temperature measurements, which means that $\mathrm{D}$ showed far more intense fire propagation than $\mathrm{A}$ or $\mathrm{B}$. However, differences were observed in temperature changes at the vent layer even between $\mathrm{A}$ and $\mathrm{B}$, in that $\mathrm{B}$ had higher temperatures than $\mathrm{A}$. These results confirmed that 


\section{MATEC Web of Conferences}

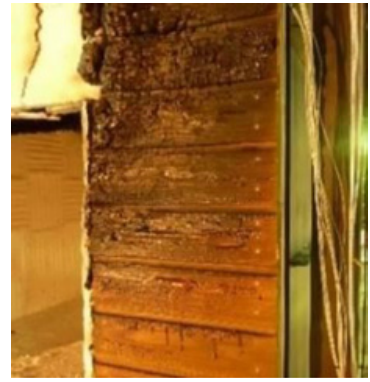

(a) Condition of leaching

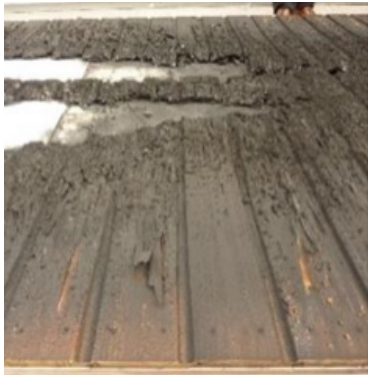

(b) Condition of peeling

Figure 8. Damage condition of specimen A (only with fire-retardant treatment).
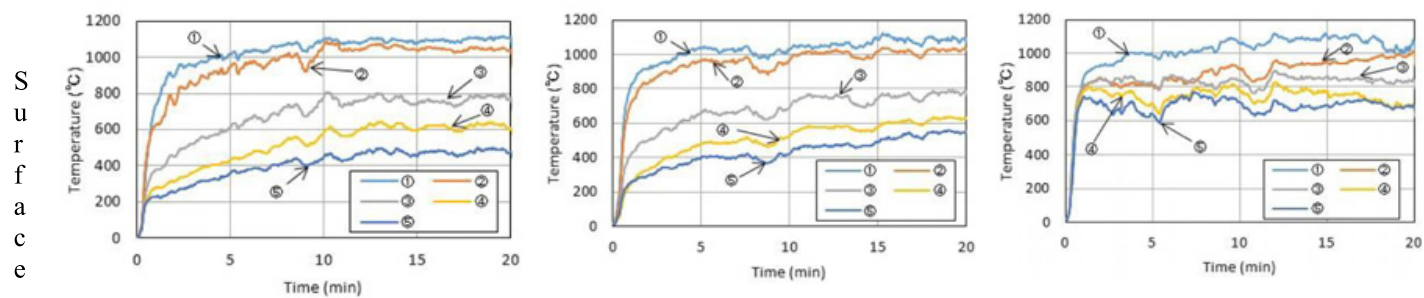

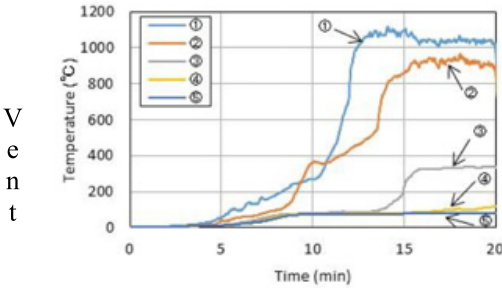

(a) Façade specimen A: Fire-retardant treatment only.

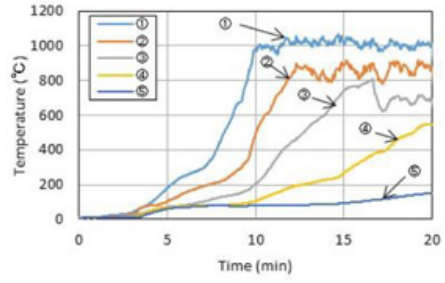

(b) Façade specimen B: Firstly, fire-retardant treated, and then, JSTM J 7001 conducted.

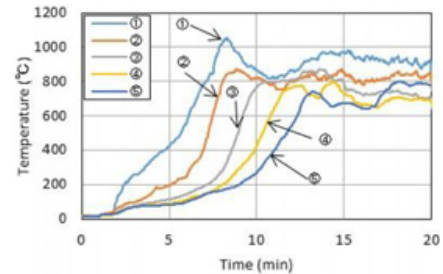

(c) Façade specimen D: No treatment at all (cedar)

(1) $500 \mathrm{~mm}$, (2) $900 \mathrm{~mm}$, (3) $1500 \mathrm{~mm}$, (4) $2000 \mathrm{~mm}$, (5) $2500 \mathrm{~mm}$ (each height from the opening top)

Figure 9. Temperature changes during the facade tests.

it is feasible to determine differences in fire-spread performance among the specimens by façade tests, while they showed no major difference by the cone calorimeter tests.

The result of the cone calorimeter tests showed that the mass reduction of A and B depends on the leached amount of fire retardant during the cone test. It turned out that A had a larger mass reduction than B. A visual record from the facade test also confirms that the amount of leached fire-retardant after the façade test is larger for $\mathrm{A}$ than $\mathrm{B}$. This indicates that the mass reduction resulting from a cone calorimeter test can be used to judge the leaching condition of the fire-retardant in a facade test.

Regarding the facade tests, the area of fire-spread over the specimen was larger with the specimen which underwent JSTM J 7001 test (one of the accelerated weathering tests), compared with the specimen without weathering test. Considering the cone calorimeter test results, it would be expected that fire will spread even more intensely for the specimens that underwent NT FIRE 053 test (another accelerated weathering test). 
$2^{\text {nd }}$ International Seminar for Fire Safety of Facades, Lund (Sweden), 2016

\section{SUMMARY}

The findings obtained from this study on reaction-to-fire performance of fire-retardant treated wood for building facades with respect to accelerated-weathering are summarized as follows:

1. Regarding the cone calorimeter tests, the specimen that underwent the JSTM J 7001 test (accelerated-weathering) resulted in the total heat released for twenty minutes $\left(14 \mathrm{MJ} / \mathrm{m}^{2}\right)$, which was just slight increase compared with the fire-retardant treated specimen without accelerated weathering $\left(12 \mathrm{MJ} / \mathrm{m}^{2}\right)$. On the other hand, the specimen that underwent the NT FIRE 053 test (different type of accelerated-weathering) was burned to a much greater degree $\left(42 \mathrm{MJ} / \mathrm{m}^{2}\right)$, which was still better than the normal cedar specimen without fire-retardant $\left(77 \mathrm{MJ} / \mathrm{m}^{2}\right)$.

2. It is tentatively concluded that the NT FIRE 053 test method produces more deterioration effect on fire-retardant treated wood than the JSTM J 7001 test, as an accelerated weathering test. This result indicates that the water sprinkling time and amount of water sprinkled during the accelerated weathering test affect the status of leaching of the fire retardant, in that total amount of watering is more with NT FIRE 053 test (6912 LTR/m² in total) than JSTM J 7001 test $\left(900 \mathrm{LTR} / \mathrm{m}^{2}\right.$ in total).

3. Regarding the JIS A 1310 façade tests, specimen with JSTM J 7001 test (accelerated-weathering) showed not so much different temperatures on the façade surface from the specimen without accelerated-weathering, while the former specimen had higher temperature increase at vent layer than the latter specimen. Fire spread slightly earlier with the former façade specimen, because fire-retardant leached out after the JSTM J 7001. But the difference is not very significant, and both the specimens showed far more moderate fire behaviour than cedar façade specimen without fire-retardant treatment.

With respect to future works, considering the specimen size of façade, NT FIRE 053 test is not very realistic option as accelerated weathering test because there is not a physically large enough laboratory in Japan for conducting with façade test size specimen, even though it is already accepted to some extent internationally, and no problem from technical viewpoint. Therefore, authors will intend to modify the test based on JSTM J 7001 with more water to be sprinkled, until cone calorimeter result will be similar to that with NT FIRE 053. And after that, the façade specimen which underwent the modified JSTM J 7001 with more watering, will be tested with JIS A 1310 façade test, to be compared with the façade specimen without accelerated weathering.

Authors greatly appreciate Dr. Tamás Bánky (ÉMI), Dr. Dhionis Dhima (CSTB) and Dr. Simo Hostikka (Aalto university), etc. on their kind help in gathering relevant information especially from European countries. Technicians and students at the University of Tokyo and Tokyo University of Science are also appreciated for their dedicating support in conducting experiments.

\section{References}

[1] Harada T., et al.: Weatherability and combustibility of fire-retardant-impregnated wood after accelerated weathering tests, Journal of Wood Science, 55(5), pp. 359-366, 2009.

[2] Östman B. and Tsantaridis L.: "Fire performance of multi-storey wooden facades," 1st International Seminar for Fire Safety of Facades, November 2013, Paris, France.

[3] Belloncle C., et al.: "Artificial and natural weathering of fire proofed wood cladding," 1st International Seminar for Fire Safety of Facades, November 2013, Paris, France.

[4] JIS A 1310: 2015, Test method for fire propagation over building façades.

[5] Yoshioka H., et al.: "Façade Tests on Fire Propagation along Combustible Exterior Wall Systems", Fire Science and Technology, 33 No. 1, pp. 1-15, 2014. 


\section{MATEC Web of Conferences}

[6] ISO 5660-1, Reaction-to-fire tests - Heat release, smoke production and mass loss rate - Part 1: Heat release rate (cone calorimeter method) and smoke production rate (dynamic measurement).

[7] NT FIRE 053: Accelerated Weathering of Fire-Retardant Treated Wood for Fire Testing, 2003.

[8] JSTM J 7001: 1996, Test method for thermal deformation and durability of real-scale exterior wall (in Japanese). 